\title{
Identifikasi Genangan Banjir di Wilayah DKI Jakarta Menggunakan Citra Satelit Sentinel-1
}

\author{
Identification of Flood Inundation in DKI Jakarta Area Using Sentinel-1 Satellite Imagery
}

Ana Mardhiyana Alawiyah' ${ }^{1}$, Harintaka ${ }^{2}$

${ }^{1}$ Alumni Sarjana Teknik Geodesi FT Universitas Gadjah Mada, Indonesia

${ }^{2}$ Staf Pengajar Departemen Teknik Geodesi FT Universitas Gadjah Mada, Indonesia

Penulis Korespondensi: Harintaka | Email: harintaka@ugm.ac.id

\author{
Diterima (Received): 10/08/2021 Direvisi (Revised): 10/11/2021 Diterima untuk Publikasi (Accepted): 08/12/2021
}

\begin{abstract}
ABSTRAK
Provinsi DKI Jakarta merupakan wilayah dengan karakteristik topografi yang berada pada kemiringan lereng relatif landai dan terletak pada dataran rendah. Hal ini menyebabkan wilayah Jakarta menjadi semakin rentan tergenang air dan banjir pada musim hujan. Pada awal tahun 2020, Jakarta mengalami banjir yang diakibatkan oleh hujan lebat yang turun sejak 31 Desember 2019 hingga 1 Januari 2020. Untuk keperluan antisipasi dan mitigasi bencana terkait banjir tersebut diperlukan ketersediaan data tentang luas genangan banjir dan letaknya secara cepat. Salah satu teknologi yang potensial untuk diterapkan adalah menggunakan citra satelit Sentinel-1. Berdasarkan kondisi tersebut, telah dilakukan kajian untuk mendeteksi daerah terdampak genangan banjir dari citra satelit Sentinel1. Adapun teknik yang digunakan adalah metode change detection dan thresholding. Pada kajian ini digunakan citra Sentinel-1 perekaman tahun 2019 dan 2020, DEMNAS, Global Surface Water dan batas administrasi wilayah DKI Jakarta. Adapun tahapan pelaksanaan kajian mencakup proses change detection dengan ratio image dari dua citra Sentinel-1 GRD sebelum dan saat banjir, perhitungan nilai optimum threshold untuk menentukan banjir dan tidak banjir, masking banjir, dan perhitungan luas genangan. Berdasarkan hasil kajian diperoleh luas total daerah yang terkena banjir sekitar 1.156,84 hektar, sedangkan luas area banjir dari data Pemprov DKI sekitar 12.896,35 hektar. Hasil validasi menggunakan data Pemprov DKI dengan membandingan antara citra Sentinel-1 tahun 2019 dan 2020, diperoleh hasil 61 lokasi atau sekitar 28,96\% termasuk ke dalam hasil interpretasi kelas banjir dan terdapat 157 lokasi atau sekitar 71,04\% termasuk ke dalam hasil interpretasi kelas tidak banjir.
\end{abstract}

Kata Kunci: DKI Jakarta, Genangan Banjir, Synthetic Aperture Radar (SAR), Sentinel-1

\section{ABSTRACT}

DKI Jakarta Province is an area with topographical characteristics that is on a relatively flat slope and is located in the lowlands. This causes the Jakarta area to become increasingly vulnerable to inundation and flooding during the rainy season. In early 2020, a serious flood-affected Jakarta, this flood was caused by heavy rain that occurred on December 31, 2019, until January 1, 2020. For the purposes of anticipating and mitigating disasters related to floods, it is necessary to provide data on the area offlood inundation and its location quickly. One technology that has the potential to be applied is the use of Sentinel-1 satellite imagery. Based on these conditions, a study has been carried out to detect areas affected by flood inundation from Sentinel-1 satellite images. The technique used is the method of change detection and thresholding. This study uses Sentinel-1 images recorded in 2019 and 2020, DEMNAS, Global Surface Water and map of the administrative boundaries of DKI Jakarta area. The stages of the study include the change detection process with ratio images from two Sentinel-1 GRD images before and during the flood, calculation of optimum threshold to determine flood and non-flood, flood masking, and calculation of inundation area. Based on the results, the total area affected by flooding is around 1,156.84 hectares, while the flood area from DKI Provincial Government data is around 12,896.35 hectares. The results of the validation using data from the DKI Provincial Government by comparing the Sentinel-1 images in 2019 and 2020, obtained 61 locations or about 28.96\% included in the flood class and 157 locations or around $71.04 \%$ including the non-flood class.

Keywords: DKI Jakarta, Inundation Flood, Synthetic Aperture Radar (SAR), Sentinel-1

(C) Author(s) 2021. This is an open access article under the Creative Commons Attribution-ShareAlike 4.0 International License (CC BY-SA 4.0). 


\section{Pendahuluan}

Kondisi topografi Provinsi DKI Jakarta berada pada dataran rendah dengan tingkat kemiringan lereng berkisar 0-3 persen. Kondisi kemiringan lereng di Jakarta termasuk ke dalam kategori yang relatif landai dan terdapat 13 sungai yang mengalir di wilayah Provinsi DKI Jakarta, serta semakin rendahnya daerah resapan air menyebabkan terjadinya run off yang makin besar. Hal ini mengakibatkan wilayah DKI Jakarta menjadi semakin rentan untuk terjadi banjir pada musim hujan (Bappeda DKI Jakarta, 2013). Menurut Deputi Bidang Klimatologi Badan Meteorologi Klimatologi dan Geofisika (BMKG), pada 1 Januari 2020 wilayah Jakarta diguyur oleh hujan lebat dimana curah hujan tersebut tertinggi sepanjang adanya pencatatan hujan di Jakarta dan sekitarnya sejak tahun 1866. Curah hujan ekstrem pada awal tahun 2020 menjadi salah satu penyebab terjadinya banjir di Jakarta dan juga diakibatkan karena adanya perubahan iklim. Intensitas hujan yang tinggi menyebabkan tinggi muka pintu air Katulampa lebih dari $110 \mathrm{~cm}$, hal ini menimbulkan luapan sungai ciliwung sehingga mengakibatkan banjir di beberapa titik wilayah Jakarta (BNPB, 2020).

Dari aspek teknologi, penginderaan jauh sudah semakin banyak digunakan dalam monitoring bencana banjir, baik menggunakan sensor optik ataupun sensor aktif, termasuk radar. Citra satelit dengan sensor radar mulai banyak dimanfaatkan untuk kajian bencana alam disebabkan beberapa keunggulan yang dimilikinya, antara lain: dapat meliput wilayah yang cukup luas, dapat menembus awan, perekaman pada waktu siang dan malam hari dalam segala cuaca karena menggunakan gelombang radio (microwave) untuk melakukan pengamatan permukaan bumi (Kushardono dan Arief, 2020). Teknologi ini mampu menutupi beberapa kelemahan yang dimiliki citra satelit optis.

Trinugroho dan Mawardi, (2018) telah melakukan pemantauan genangan air menggunakan citra satelit Landsat 7 secara temporal dari tahun 2010 hingga 2013 pada Rawa Lebak, Kalimantan Selatan. Teknik yang dilakukan dengan interpretasi dan mendeliniasi genangan air. Hasil kajian menunjukkan kondisi maksimum area genangan pada tahun 2012. Octarina, dkk. (2019) juga melakukan deteksi genangan di wilayah DKI Jakarta menggunakan Landsat 8 dengan memanfaatkan saluran Green-Short Wave Infrared. Hasil kajian menunjukkan metode tersebut mampu memperjelas batas antara air dan non air.

Penggunaan teknologi penginderaan jauh dengan sensor radar juga mulai banyak digunakan untuk kajian banjir. Pradana, dkk. (2020) melakukan analisis daerah tergenang di Desa Kabupaten Malang menggunakan data SAR Sentinel-1 dengan interpretasi dan komposit saluran RGB. Hasil yang diperoleh berupa peta daerah tergenang banjir yang didasarkan pada tiga aspek yaitu, topografi, soil saturation dan area tergenang banjir. Fajrin, dkk. (2020) juga menggunakan citra Sentinel-1 untuk mendeteksi banjir di Koto Baru Sumatera Barat menggunakan metode interpolasi bilinear dan thresholding. Hasil dari penelitian ini menunjukkan sebagian besar wilayah Koto Baru Sumatera Barat dilanda banjir.

Dalam perspektif pemrosesan data citra satelit, saat ini berkembang teknologi pemrosesan citra satelit berbasis cloud computing yang menyediakan data penginderaan jauh dalam jumlah yang besar untuk mencapai target yang sulit dicapai ketika melakukan pemrosesan secara konvensional. Pada teknologi cloud computing ini dapat melakukan analisis data citra dalam skala besar (big data analysis) dan mampu mengintegrasikan sumber data yang berbeda-beda. Salah satu penggunaan big data analysis dalam penginderaan jauh yaitu untuk deteksi tumpahan minyak di laut secara otomatis (Chi, dkk., 2016). Salah satu platform cloud computing yang sangat populer untuk memproses data-data kebumian adalah Google Earth Engine.

Berdasarkan permasalahan banjir yang dihadapi oleh DKI Jakarta, perlu dilakukan kajian tentang deteksi genangan banjir di wilayah DKI Jakarta secara cepat. Dari hasil yang diperoleh harapannya dapat menjadi alternatif masukkan dalam pengambilan kebijakan, sehingga daerahdaerah yang terdampak banjir mendapat perhatian lebih dalam upaya mitigasi dan evakuasi bencana banjir. Pada kajian ini digunakan citra satelit Sentinel -1 sebelum (preflood) dan saat banjir (flood) dengan memanfaatkan platform cloud computing Google Earth Engine untuk pemrosesan datanya. Untuk identifikasi banjir di wilayah DKI Jakarta digunakan metode change detection menggunakan ratio image dari dua citra Sentinel-1 pada citra sebelum dan saat banjir dan thresholding untuk menentukan optimum threshold dalam identifikasi kelas banjir dan non-banjir. Berdasarkan genangan banjir yang terdeteksi dilakukan masking kemiringan lereng dan badan air permanen untuk meminimalkan kesalahan perkiraan banjir. Hasil kajian yang berupa prediksi persebaran genangan banjir yang diharapkan dapat menjadi pertimbangan dalam mitigasi bencana banjir.

\section{Data dan Metodologi}

\subsection{Data dan Lokasi}

Lokasi kajian mencakup wilayah Provinsi DKI Jakarta yang terdiri atas lima wilayah kota administrasi, yaitu: Kota Jakarta Pusat, Jakarta Utara, Jakarta Barat, Jakarta Selatan, dan Jakarta Timur. Data yang digunakan berupa citra Satelit Sentinel-1, DEMNAS, Data Global Surface Water, batas administrasi Provinsi DKI Jakarta, dan data pantau banjir yang dirilis oleh Pemprov DKI Jakarta.

Citra satelit Sentinel-1 berupa citra yang direkam sebelum dan saat/setelah kejadian banjir (rekaman tanggal 6 Juli 2019 dan 2 Januari 2020). Data DEMNAS merupakan data DEM yang dirilis oleh BIG di situs: http://tides.big.go.id/, dan digunakan untuk masking kemiringan lereng. Data Global Surface Water yang diakses pada cloud GEE untuk masking badan air permanen. Data batas administrasi Provinsi DKI Jakarta yang diperoleh secara online melalui Geoportal Provinsi DKI Jakarta (https://jakartasatu.jakarta.go.id/). Data lokasi banjir pada tanggal 2 Januari 2020 diperoleh dari situs Pantau Banjir milik Pemprov DKI Jakarta (http:// 
apps.smartcity.jakarta.go.id/pantau-banjir-v3/). Adapun perangkat lunak yang digunakan untuk pengolahan data adalah platform Google Earth Engine berbasis cloud computing dan QGIS.

\subsection{Metodologi}

Tahapan pelaksanaan penelitian ditunjukkan pada Gambar 1. Tahap pertama adalah membatasi daerah kajian di wilayah DKI Jakarta. Citra satelit Sentinel-1 tahun 2019 dan 2020 dilakukan filtering, change detection, hitungan optimum threshold, dan masking daerah terdeteksi banjir menggunakan data global surface water. Dari area tergenang yang terdeteksi dilakukan klasifikasi kelas kedalaman banjir dan tahap terakhir adalah validasi hasil.

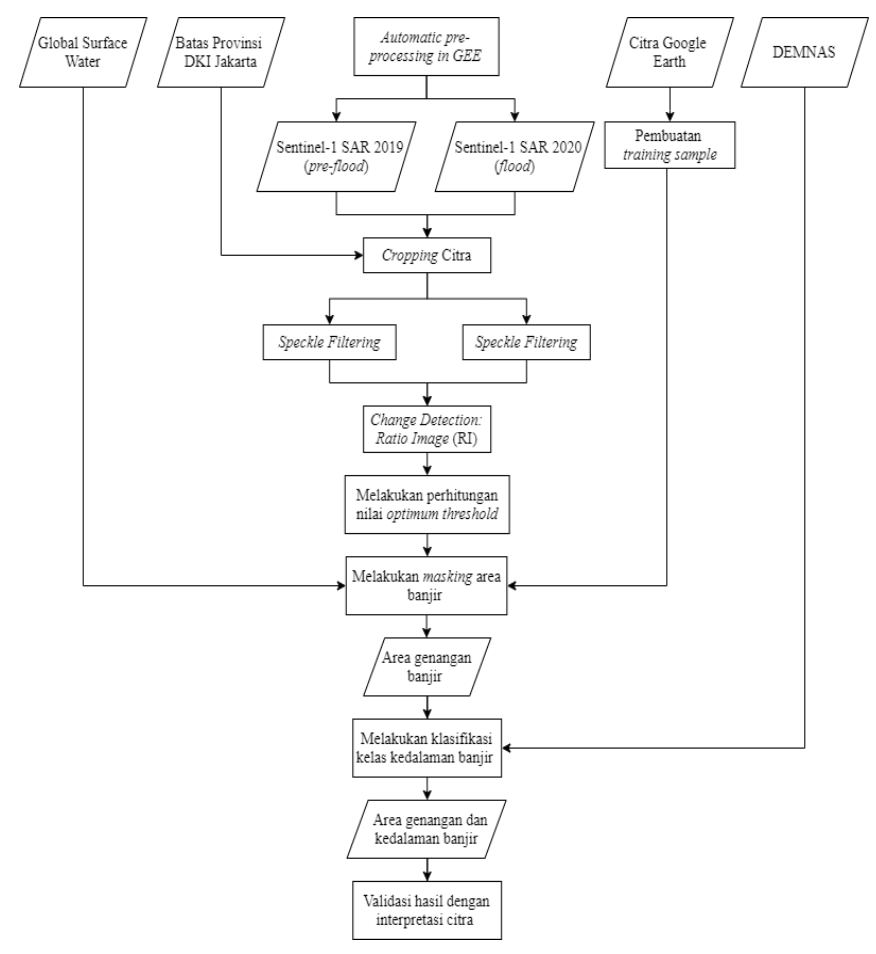

Gambar 1 Diagram alir pelaksanaan penelitian

\subsubsection{Pre-processing citra satelit Sentinel-1.}

Data yang digunakan meliputi 2 scene citra satelit Sentinel-1 sebelum kejadian banjir (tanggal perekaman 6 Juli 2019) dan saat/sesudah kejadian banjir (tanggal perekaman 2 Januari 2020). Data citra satelit Sentinel-1 yang digunakan adalah level-1 Ground Range Detected (GRD) yang berarti data citra sudah diproyeksikan geometrinya terhadap ellipsoid WGS 84 dan tidak terdapat informasi data fase (ESA, 2021).

Tahapan pre-processing yang telah dilakukan mencakup, apply orbit file, GRD border noise removal, thermal noise removal, radiometric calibration, terrain correction (orthorectification), serta konversi nilai hamburan balik $\left(\sigma^{\circ}\right)$ ke satuan desibel $(\mathrm{dB})$. Tahapan setelah pre-processing adalah filtering. Beberapa parameter data yang perlu diperhatikan pada tahap ini adalah jenis polarisasi yang dipilih (misal polarisasi Vertikal Vertikal (VV), mode instrument IW, arah orbit ascending, dan resolusi spasial (misal $10 \mathrm{~m}$ ).

\subsubsection{Speckle filtering}

Sebelum dilakukan speckle filtering, citra satelit perlu dilakukan pemotongan sesuai daerah kajian, dalam hal ini wilayah DKI Jakarta. Tahap speckle filtering diperlukan untuk menghilangkan noise yang terdapat pada citra. Umumnya efek speckle noise berupa bercak-bercak hitam putih yang timbul akibat gangguan gelombang yang dipantulkan oleh objek di permukaan bumi yang mengganggu hamburan balik sinyal radar. Pada tahap ini hanya diterapkan filter penghalusan/smoothing pada citra menggunakan radius 50 meter untuk mengurangi adanya efek speckle tersebut.

\subsubsection{Change detection}

Teknik change detection yang digunakan untuk identifikasi genangan banjir dari 2 waktu tersebut adalah Ratio Image (RI). RI merupakan salah satu metode deteksi perubahan dengan membandingkan piksel per piksel pada citra saat terjadi dan sebelum banjir. Ratio Image dihasilkan dengan menghitung rasio nilai koefisien hamburan balik $\left(\sigma^{\circ}\right)$ pada citra saat terjadi banjir dan sebelum banjir. Persamaan matematis yang digunakan adalah (Vanama, dkk., 2021):

$$
R I=\frac{\sigma_{v v(\text { flood })}^{\circ}}{\sigma_{v v(\text { pre }- \text { flood })}^{\circ}}
$$

Keterangan:

$\sigma_{v v(\text { flood })}^{\circ}=$ Koefisien hamburan balik citra saat terjadi banjir dari polarisasi VV

$\sigma_{v v(\text { pre-flood })}^{\circ}=$ Koefisien hamburan balik citra sebelum terjadi banjir dari polarisasi VV

Jika koefisien hamburan balik yang dipantulkan pada kedua citra sama, maka nilai RI $=1$. Hal ini mengindikasikan tidak ada perubahan antara 2 waktu tersebut. Pada daerah yang mengalami perubahan, nilai rasio akan jauh lebih besar dari 1 atau kurang dari 1, tergantung dari perubahan pada kedua citra. Nilai piksel yang tinggi, pada citra ditandai dengan warna yang cerah untuk area yang perubahan tinggi. Sementara nilai yang rendah, pada citra ditandai dengan warna yang gelap untuk area yang terindikasi perubahan yang rendah.

\subsubsection{Perhitungan threshold}

Nilai optimum threshold diperlukan untuk mengidentifikasi daerah banjir. Nilai piksel dari POI (Point of Interest), seperti air dan perkotaan diekstraksi dari nilai indeks rasio hasil deteksi perubahan. Data latih (training dataset) diperlukan untuk menghasilkan nilai optimum threshold pada kelas tutupan lahan seperti badan air dan perkotaan dan dibuat secara interaktif dengan melakukan digitasi pada citra Google Earth. Data POI yang digunakan, kemudian ditampalkan kan pada citra SAR hasil proses change detection untuk dilakukan perhitungan statistik. Penentuan optimum threshold menggunakan persamaan (Vanama, dkk., 2021): 


$$
\begin{gathered}
\mu_{\text {water }}=\frac{1}{N} \sum_{i=1}^{N} \text { WaterPOI }_{i} \\
\sigma_{\text {water }}=\sqrt{\frac{1}{N-1} \sum_{i=1}^{N} \mid \text { WaterPOI }-\left.\mu_{\text {water }}\right|^{2}}
\end{gathered}
$$

Keterangan:

$\mathrm{N}=$ Jumlah sampel badan air

$\mu_{\text {water }}=$ Rata-rata dari nilai piksel badan air

$\sigma_{\text {water }}=$ Standar deviasi dari nilai piksel badan air

Dari persamaan (2) dan (3) karena menggunakan metode RI, nilai piksel non air juga digunakan dalam menentukan optimum threshold. Oleh karena itu, threshold kelas non air juga dihitung dengan $\left(\mu_{\text {urban }}+\sigma_{\text {urban }}\right)$. Nilai piksel yang berada diantara hasil threshold kelas badan air dan non air diidentifikasi sebagai daerah banjir (Vanama dkk., 2021).

\subsubsection{Masking dan klasifikasi kedalaman banjir}

Kawasan genangan banjir yang terdeteksi dilakukan masking untuk mendapatkan hasil perkiraan banjir. Proses masking dilakukan untuk kawasan banjir dengan kemiringan lereng lebih dari $3^{\circ}$. Hal tersebut dilakukan karena dalam identifikasi banjir, kemiringan lereng kurang dari $3^{\circ}$ merupakan ambang batas untuk daerah rawan banjir (Tassew, 2017). Untuk masking badan air permanen digunakan data Global Surface Water untuk meminimalkan kesalahan perkiraan banjir yang terlalu tinggi. Dalam hal ini digunakan 8 piksel atau sel disekitarnya (UNOOSA, 2020).

Secara operasional, untuk klasifikasi kedalaman banjir dari hasil masking banjir digunakan data DEMNAS. Kelas kedalaman banjir yang digunakan menyesuaikan dengan klasifikasi kedalaman banjir yang dirilis oleh Pemprov DKI Jakarta pada kejadian banjir 2 Januari 2020 (Gambar 2.). Pada kajian ini, kedalaman banjir dibagi menjadi 4 kelas, yaitu: kelas pertama dengan kedalaman banjir 10 hingga 30 $\mathrm{cm}$, kelas kedua dengan kedalaman 31 hingga $70 \mathrm{~cm}$, kelas ketiga dengan kedalaman 71 hingga $150 \mathrm{~cm}$, dan kelas keempat dengan kedalaman lebih dari $150 \mathrm{~cm}$.

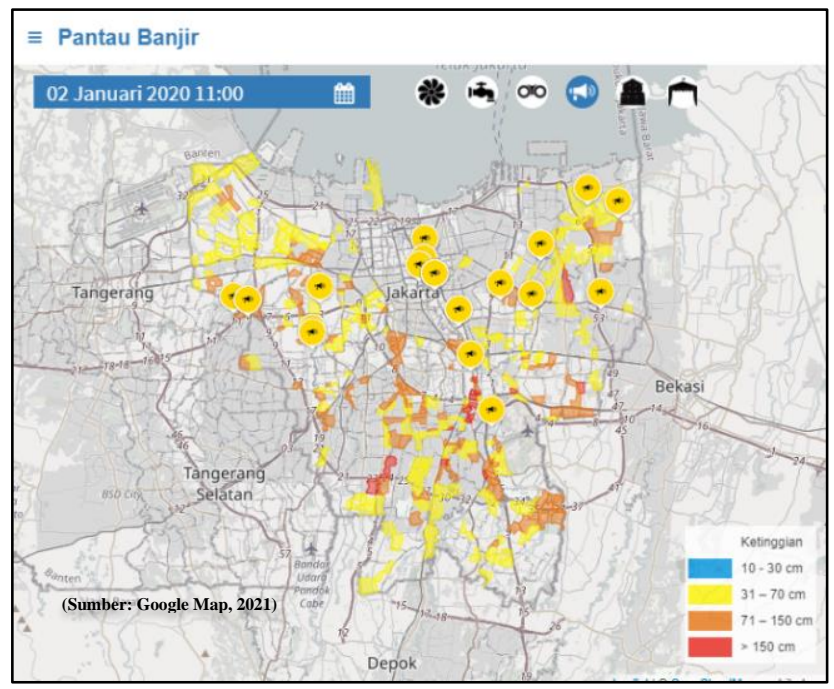

Gambar 2 Lokasi banjir dari web Pantau Banjir (http://apps.smartcity.jakarta.go.id/pantau-banjir-v3/)

\subsubsection{Validasi dengan Interpretasi Visual}

Tahap validasi dilakukan dengan uji interpretasi visual mengacu kepada data lokasi banjir Pemprov DKI. Secara visual, daerah genangan banjir dapat diinterpretasi dari citra Sentinel-1 tahun 2019 (sebelum banjir) dan citra Sentinel-1 tahun 2020 (saat ataupun sesudah banjir). Pada citra SAR (termasuk citra Sentinel-1), umumnya objek air atau genangan air akan terekam oleh citra satelit dengan warna yang gelap, sedangkan untuk objek yang tidak tergenang air akan tampak lebih cerah.

\section{Hasil dan Pembahasan}

\subsection{Proses change detection}

Prinsip change detection untuk deteksi genangan banjir adalah mendeteksi perubahan nilai backscattering dari 2 seri data citra Sentinel-1 (data pada saat kondisi sebelum banjir dan saat/sesudah terjadi banjir). Hasil proses change detection menunjukan rasio perubahan per piksel. Pada Gambar 3 sebelah kiri, daerah yang ditandai dengan kotak merupakan sampel daerah yang terkena banjir pada 2 Januari 2020 menurut data Pemprov DKI. Daerah ini berlokasi di RW 07, Kelurahan Kamal, Kecamatan Kalideres, Jakarta Barat. Pada kawasan atau Point of Interest (POI) tersebut memiliki nilai RI sebesar 1,329. Nilai ini mengindikasikan terjadi perubahan pada lokasi tersebut karena nilai $\mathrm{RI} \neq 1$. Nilai rasio akan jauh lebih besar dari 1 $(\mathrm{RI}>1)$ atau kurang dari $1(\mathrm{RI}<1)$ bergantung pada perubahan kedua citra. Piksel tampak sedikit cerah yang menandakan pada lokasi tersebut memiliki rasio nilai yang tinggi dan menunjukkan adanya perubahan yang tinggi. Sementara untuk rasio nilai yang rendah ditandai dengan piksel yang gelap yang menunjukan terjadi perubahan yang rendah.

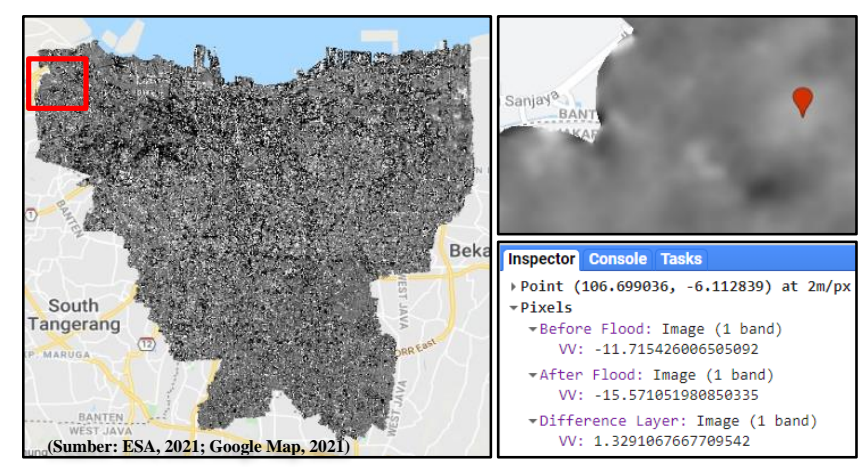

Gambar 3 Hasil change detection RI

\subsection{Proses thresholding}

Penentuan nilai optimum threshold dilakukan setelah mendapat indeks RI. Nilai optimum threshold ini digunakan untuk mengidentifikasi area banjir dan non-banjir dengan membuat sampel pada kelas badan air dan non air/perkotaan/urban (Gambar 4). Dari hasil POI sampel seperti yang ditunjukkan pada Gambar 4, kemudian ditumpang tindihkan pada citra SAR dari hasil proses RI untuk melihat nilai rasio POI tersebut. 
Berdasarkan hasil POI yang sudah dibuat dan melakukan perhitungan statistik sesuai persamaan (2) dan (3) maka didapatkan nilai threshold pada kelas badan air sebesar 1,222 dan pada kelas non air/perkotaan/urban sebesar 1,859. Berdasarkan hal tersebut, setiap nilai piksel yang berada di antara 1,222 hingga 1,859 diindikasikan merupakan daerah banjir. Hasil proses thresholding berupa layer biner menunjukan nilai 1 untuk semua piksel yang berada di antara 1,222 dan 1,859 dan nilai 0 untuk semua piksel yang tidak berada pada rentang tersebut. Layer biner (binary layer) merupakan layer yang hanya mempunyai dua nilai derajat keabuan (gray level) 0 atau 1 . Warna putih menunjukan nilai 1 untuk kelas banjir, sedangkan warna hitam menunjukan nilai 0 untuk kelas tidak banjir seperti yang ditunjukkan pada Gambar 5.

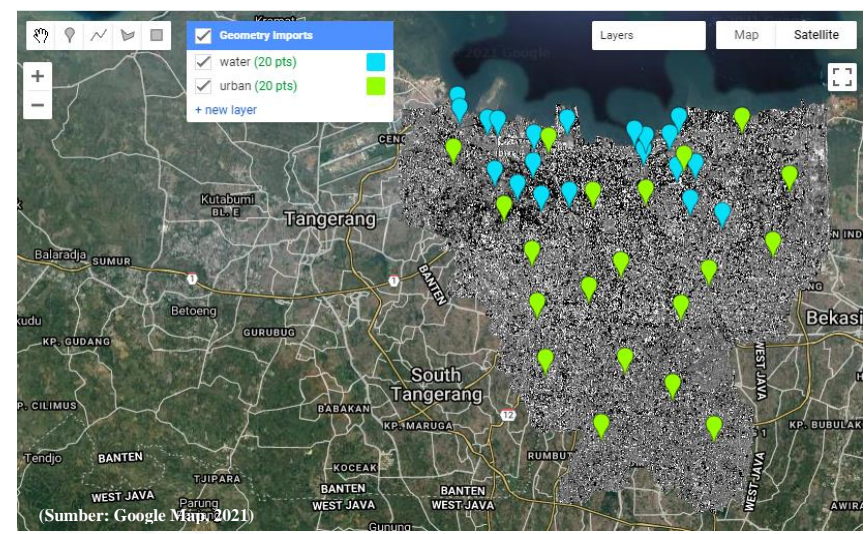

Gambar 4 Pembuatan sampel POI

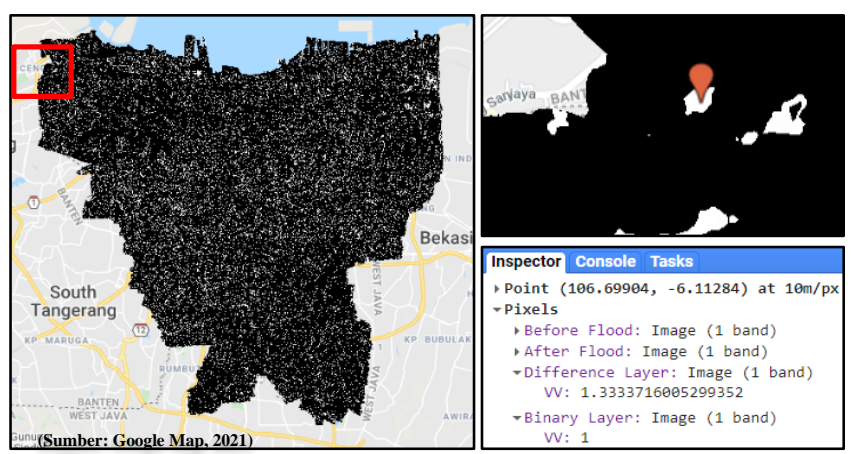

Gambar 5 Hasil thresholding

3.3. Deteksi Genangan Banjir dan Kedalaman Banjir.

Tahap terakhir dari proses deteksi genangan banjir adalah masking badan air permanen, masking kemiringan lereng, dan masking piksel/sel tetangga. Dari hasil threshold, dilakukan masking badan air permanen menggunakan data Global Surface Water dengan memanfaatkan band seasonality. Pada tahap masking kemiringan lereng, digunakan data DEMNAS untuk menghilangkan area banjir yang berada di kemiringan lereng lebih dari 3\%. Tahap terakhir, yaitu masking piksel atau sel dihitung dengan memperhatikan 8 piksel atau sel terdekat. Hasil akhir berupa kawasan yang terindikasi banjir pada tahun 2020 ditampilkan pada Gambar 6 .
Hasil kawasan yang terindikasi banjir perlu dilakukan penambahan informasi kedalaman banjir dari data DEM dan sekaligus klasifikasi. Pada kajian ini hasil klasifikasi dikelompokkan dalam 4 kelas. Hal ini untuk menyesuaikan dengan data lokasi kejadian banjir yang dirilis di situs Pantau Banjir Pemprov DKI. Gambar 7 menampilkan hasil identifikasi sebaran banjir dan kedalamannya dan contoh salah satu zoom out di suatu lokasi (kotak merah). Pada gambar tersebut disajikan 4 warna yang menunjukkan tingkat kedalaman air banjir, dari yang paling rendah (warna biru) sampai yang paling dalam (warna merah, dengan kedalaman lebih besar daripada $150 \mathrm{~cm}$ ).

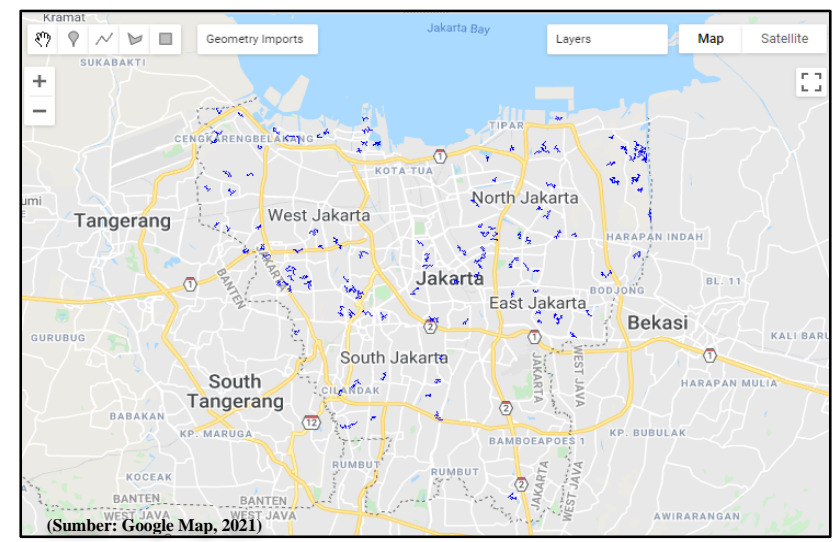

Gambar 6 Hasil identifikasi banjir Jakarta 2 Januari 2020

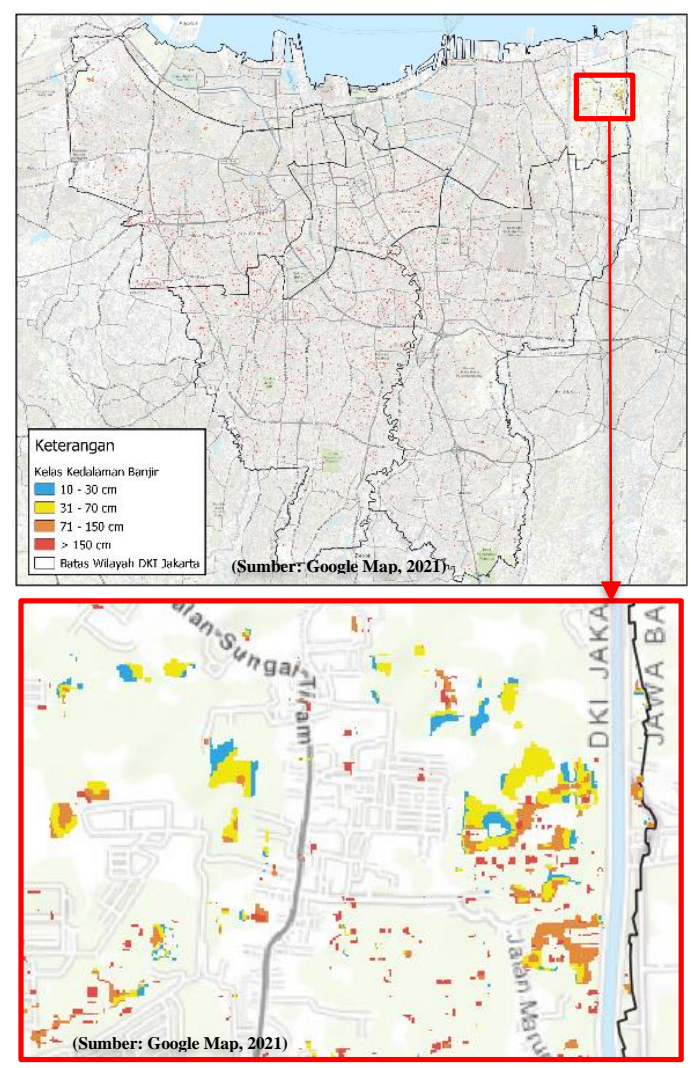

Gambar 7. Hasil identifikasi sebaran banjir dan kedalamannya dan contoh zoom out. 


\subsection{Luas Genangan Banjir}

Perhitungan luas genangan banjir ditabulasikan untuk setiap kota di wilayah DKI Jakarta. Proses hitungan luas genangan air ini dapat dilakukan secara cloud computing menggunakan platform GEE. Hasil hitungan luas genangan banjir disajikan pada Tabel 3.1. Berdasarkan hasil perhitungan luas yang diperoleh, luas area banjir pada tiap kota di Jakarta pada tanggal 2 Januari 2020 adalah sekitar 220 ha di Jakarta Timur, 310 ha di Jakarta Utara, 258 ha di Jakarta Barat, 110 ha di Jakarta Pusat, dan 257 ha di Jakarta Selatan. Wilayah Jakarta Utara merupakan wilayah yang terdampak banjir paling luas dari tiap kota di DKI Jakarta (Gambar 8).

Tabel 3.1 Luas genangan banjir tiap kota

\begin{tabular}{clr}
\hline No & Kota di DKI Jakarta & \multicolumn{1}{c}{ Luas (ha) } \\
\hline $\mathbf{1}$ & Jakarta Barat & 258,304 \\
$\mathbf{2}$ & Jakarta Pusat & 110,580 \\
$\mathbf{3}$ & Jakarta Selatan & 257,021 \\
$\mathbf{4}$ & Jakarta Timur & 220,881 \\
$\mathbf{5}$ & Jakarta Utara & 310,058 \\
\hline & Total luas genangan & $1.156,843$ \\
\hline
\end{tabular}

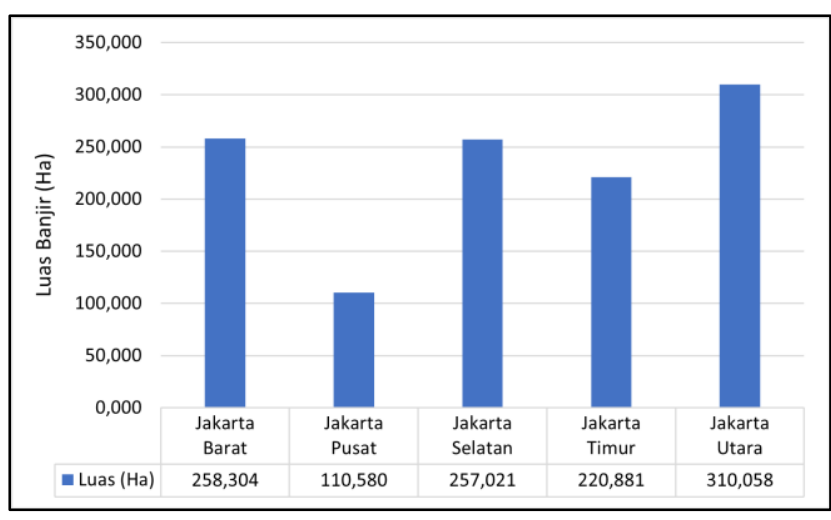

Gambar 8 Luas banjir tanggal 2 Januari 2020 di DKI Jakarta

\subsection{Validasi}

Validasi hasil deteksi genangan banjir yang diturunkan dari citra satelit Sentinel-1 dilakukan dengan cara interpretasi visual dan dibandingkan dengan data lokasi banjir yang dirilis oleh Pemprov DKI. Contoh hasil validasi dapat dilihat pada Gambar 9.

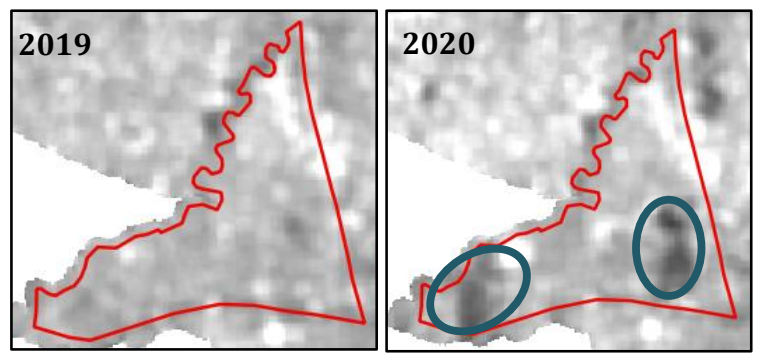

(a)

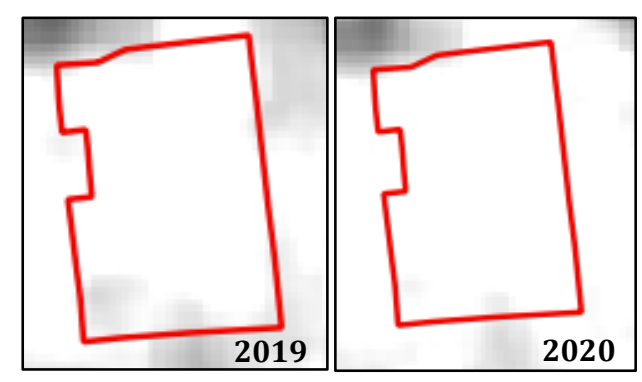

(b)

Gambar 9 Perbandingan tampilan citra sebelum dan sesudah (a) pada saat terjadi banjir; (a) pada saat tidak banjir

Pada citra SAR, termasuk Sentinel-1, umumnya untuk objek air ataupun genangan air akan terekam dengan warna gelap, sedangkan untuk objek yang tidak tergenang akan tampak cerah. Ini menjadi salah satu kunci untuk melakukan interpretasi pada citra satelit sentinel. Hal ini dapat menjadi pembeda pada saat kondisi sebelum terjadi banjir dan pada saat atau sesudah terjadi banjir. Pada Gambar 9 (a) sangat terlihat jelas perbedaannya pada citra tahun 2019 dan tahun 2020. Pada bagian yang dilingkari tampak berwarna gelap pada citra Sentinel tahun 2020, yang dapat dinyatakan pada daerah tersebut terdapat genangan atau terjadi banjir, sedangkan pada Gambar 9 (b) tidak terlihat perbedaan pada Sentinel-1 tahun 2019 dengan tahun 2020, sehingga dapat dinyatakan pada area tersebut tidak terjadi banjir. Ini diperkuat dengan data yang dirilis oleh Pemprov DKI Jakarta.

Hasil validasi menggunakan data Pemprov DKI dengan membandingan antara citra Sentinel-1 tahun 2019 dan 2020, diperoleh hasil 61 lokasi atau sekitar 28,96\% termasuk ke dalam hasil interpretasi kelas banjir dan terdapat 157 lokasi atau sekitar 71,04\% termasuk ke dalam hasil interpretasi kelas tidak banjir. Catatan penting yang diperoleh adalah, tahapan interpretasi visual cukup sulit dilakukan dalam identifikasi objek pada citra Sentinel-1 antara banjir dan tidak banjir di daerah perkotaan. Hal ini kemungkinan terbesar disebabkan oleh jenis backscattering radar adalah double-bounce scatterers.

Double-bounce merupakan daerah dimana backscattering radar sangat tinggi sebagai efek pantulan balik sinyal radar karena adanya pantulan dari gedung dan bangunan. Daerah double-bounce scattering berupa objek bangunan, batang pohon, tiang lampu, dan struktur vertikal lainnya yang dapat membelokkan hamburan awal ke sensor (Flores-Anderson, dkk., 2019). Pada citra SAR, termasuk Sentinel-1 GRD, tampilan pada daerah double bounce berupa piksel yang terang atau sinyal backscattering tinggi, sehingga jika terjadi banjir identifikasi genangan sulit dilakukan karena tampilan air yang seharusnya tampak berwarna gelap akibat sinyal backscattering rendah, pada citra jadi tidak terlalu tampak gelap akibat adanya pantulan dari gedung dan bangunan. 


\section{Kesimpulan}

Berdasarkan hasil dan pembahasan yang telah dilakukan dapat disimpulkan bahwa:

1. Identifikasi daerah terkena banjir di wilayah DKI Jakarta menggunakan metode change detection antara dua data set citra Sentinel-1 tahun 2019 dan 2020 diperoleh luas daerah yang terkena banjir pada periode 2 Januari 2020 adalah sekitar 220 ha di Jakarta Timur, 310 ha di Jakarta Utara, 258 ha di Jakarta Barat, 110 ha di Jakarta Pusat, dan 257 ha di Jakarta Selatan.

2. Hasil identifikasi daerah genangan banjir pada pada citra Sentinel-1 menggunakan metode change detection dan thresholding masih dipengaruhi noise dan juga adanya efek bayangan pada citra akibat perbedaan sudut pengambilan citra.

3. Hasil interpretasi dan validasi dengan citra Sentinel-1 tahun 2019 dan tahun 2020 menggunakan 221 data sampel lokasi banjir Pemprov DKI diperoleh hasil bahwa terdapat 61 lokasi atau sekitar 28,96\% termasuk ke dalam hasil interpretasi kelas banjir dan terdapat 157 lokasi atau sekitar 71,04\% termasuk ke dalam hasil interpretasi kelas tidak banjir.

\section{Pernyataan Konflik Kepentingan}

Penulis menyatakan tidak ada konflik kepentingan dalam artikel ini (The authors declare no competing interest).

\section{Referensi}

Badan Nasional Penanggulangan Bencana (BNPB). (2020). Infografis Banjir Jakarta, Banten Dan Jabar 10 Januari 2020. https://bnpb.go.id/infografis/infografisbanjir-jakarta-januari-2020

Bappeda DKI Jakarta. (2013). Rencana Pembangunan Jangka Menengah Daerah Provinsi Jakarta Tahun 2013-2017. 1-165.

Chi, M., Plaza, A., Benediktsson, J. A., Sun, Z., Shen, J., \& Zhu, Y. (2016). Big Data for Remote Sensing: Challenges and Opportunities. Proceedings of the IEEE, 104(11), 2207-2219. https://doi.org/10.1109/JPROC.2016.2598228

European Space Agency (ESA). (2021). Product Types and Processing Level-1.

Fajrin, Adha, M. Y., \& Armi, I. (2020). Pemanfaatan Citra Sentinel-1 SAR Untuk Deteksi Banjir Studi Kasus Pangkalan Koto Baru Sumatera Barat. October 2019. https://doi.org/10.21063/SPI4.2019.u

Flores-Anderson, A. I., Herndon, K. E., Thapa, R. B., \& Cherrington, E. (2019). Sampling Designs for SARAssisted Forest Biomass Surveys. THE SAR HANDBOOK Comprehensive Methodologies for Forest Monitoring and Biomass Estimation, 1-307. https://doi.org/10.25966/nr2c-s697

Kushardono, D., \& Arief, R. (2020). Pemanfaatan Data Satelit Radar untuk Wilayah Darat di Indonesia: Peluang dan Tantangan (pp. 1-232). LIPI Press.
Octarina, T. M., Putra, I. D. N. N., \& Wirdiani, N. K. A. (2019). Penginderaan Jauh Pemrosesan Data Satelit Landsat 8 Untuk Deteksi Genangan. Jurnal Ilmiah Merpati (Menara Penelitian Akademika Teknologi Informasi), $7(1)$, 77. https://doi.org/10.24843/jim.2019.v07.i01.p09

Pradana, I. H., Irawan, L. Y., Setiawan, D., \& ... (2020). Analisis Daerah Tergenang Banjir Di Desa Sitiarjo, Kabupaten Malang Menggunakan Data SAR (Synthetic Aperture Radar) Sentinel-1. Jurnal Georafflesia ..., 3, 58-67.

https://journals.unihaz.ac.id/index.php/georafflesia /article/view/1347

Tassew, G. T. (2017). Flood Detection and Mapping Using Microwave Remote Sensing; A Case Study on Lake Koka Cachment, Awash River Basin, Ethiopia [Thesis, Addis Ababa University]. AAU Institutional Repository. http://213.55.95.56/handle/123456789/6610

Trinugroho, M. W., \& Mawardi. (2018). Pemantauan Area Genangan Air Pada Rawa Lebak Menggunakan Teknologi Penginderaan Jauh. Jurnal Ilmiah Geomatika, 23(2), 49. https://doi.org/10.24895/jig.2017.23-2.716

United Nations Office for Outer Space Affairs (UNOOSA). (2020). Step-by-Step: Recommended Practice: Flood Mapping and Damage Assessment using Sentinel-1 SAR data in Google Earth Engine. https://unspider.org/advisory-support/recommen dedpractices/recommended-practice-google-earthengine-flood-mapping/step-by-step

Vanama, V. S. K., Rao, Y. S., \& Bhatt, C. M. (2021). Change detection based flood mapping using multi-temporal Earth Observation satellite images: 2018 flood event of Kerala, India. European Journal of Remote Sensing, 54(1), 42-58. https://doi.org/10.1080/22797254.2020.1867901 